\title{
Correction: Identifying Ontario geographic regions to assess adults who present to hospital with laboratory-defined conditions: a descriptive study
}

An error occurred in an article published Oct. 22, 2019. ${ }^{1}$

In Table 1, the headers "Catchment area of OLIS-linked hospitals" and "Catchment area of unlinked hospitals" were switched.

This has been corrected at cmajopen.ca. CMA7 Open apologizes for the error.

\section{Reference}

1. Iskander C, McArthur E, Nash DM, et al. Identifying Ontario geographic regions to assess adults who present to hospital with laboratory-defined conditions: a descriptive study. CMAf Open 2019;7:E624-E629.

CMAJ Open 2020. DOI:10.9778/cmajo.20200028 